\title{
The Use of Polyacrylamide Gel Electrophoresis in Taxonomy of Brucella
}

\author{
By J. A. MOR RIS \\ Ministry of Agriculture, Fisheries and Food, \\ Central Veterinary Laboratory, Weybridge, Surrey
}

(Received I9 December 1972)

\begin{abstract}
SUMMARY
Polyacrylamide gel electrophoresis was used to compare bacterial proteins of Brucella abortus, $B$. melitensis and $B$. suis and of the relatively new members of the genus, $B$. neotomae, $B$. canis and $B$. ovis. With the exception of the two representatives of a new fifth biotype of $B$. suis, all the protein patterns were identical. Yersinia enterocolitica $I X$ and $Y$. enterocolitica NCTCI046I gave indistinguishable protein patterns which were distinct from those of Brucella. The results suggest that $B$. neotomae, $B$. canis and $B$. ovis are assigned to the correct genus but indicate that the taxonomic status of the $B$. suis biotype 5 representatives should be re-examined.
\end{abstract}

\section{INTRODUCTION}

In systematic bacteriology, techniques which compare the bacterial genome appear to be the most accurate in determining genetic similarity among bacteria (e.g. Hill, I966; Heberlein, Deley \& Tijtgat, I967). Recently, DNA homology studies have been successfully applied to the taxonomy of Brucella (Hoyer \& McCullough, I968 $a, b$ ) but such studies require specialized equipment and are very time-consuming. Since protein structure is genetically determined it is often possible to compare regions of bacterial DNA indirectly by comparing the electrophoretic patterns of bacterial proteins. Thus, electrophoresis of proteins has proved a convenient alternative to direct nucleic acid studies in the classification of organisms such as Streptomyces (Gottlieb \& Hepden, I966), Mycoplasma (Razin \& Rottem, 1967), microaerophilic vibrios (Morris \& Park, 1970) and Mycobacterium (Haas, Davidson \& Sacks, 1972).

In the present study the protein electrophoretograms of members of the three classical species of Brucella (namely Brucella abortus, B. melitensis and $[B$. suis) were examined together with the relatively new members of the genus, $B$. neotomae, $B$. canis and $B$. ovis. Yersinia enterocolitica $I X$, which cross-reacts serologically with Brucella, and Y.enterocolitica NCTCI046r were also studied. The protein patterns obtained were of value in determining the similarity between recognized members of the genus and allowed the taxonomic status of two representatives of a new fifth biotype of $B$. suis (Renoux \& Philippon, I969) to be assessed.

\section{METHODS}

Bacteria. With the exception of two strains designated Brucella suis biotype 5, which were donated by Dr A. Philippon as freeze-dried cultures labelled B58 and 4607, all the bacteria were from the culture collection maintained at this laboratory (Table I). The 36 Brucella cultures from the laboratory collection had been previously characterized by the methods 
Table I. Bacteria examined

\begin{tabular}{|c|c|c|}
\hline Species & Biotype & Strain \\
\hline Brucella abortus & $\begin{array}{l}1 \\
2 \\
3 \\
4 \\
5 \\
6 \\
7 \\
8 \\
9\end{array}$ & $\begin{array}{l}544, \text { SI } 9,45 / 20, \text { s99 } \\
808 / 67,1045 / 67 \\
3 / 68 \\
126 / 68,240 / 68 \\
96 / 67 \\
26 / 64,1295 / 67 \\
63 / 294,63 / 76 \\
\text { ND } \\
\text { 30/68,237/68 }\end{array}$ \\
\hline B. melitensis & $\begin{array}{l}I \\
2 \\
3\end{array}$ & $\begin{array}{l}\text { I } 6 \mathrm{M}, \text { REVI, } 23 / 65,72 / 65,83 / 65 \\
9 / 63, \text { I I } 4 / 63 \\
323 / 63,43 / 65\end{array}$ \\
\hline B. suis & $\begin{array}{l}\text { I } \\
2 \\
3 \\
4 \\
5\end{array}$ & $\begin{array}{l}\text { I } 330, \text { I } 87 / 63 \\
258 / 63,266 / 63 \\
\mathrm{P} 4 / \mathrm{I} \mathrm{I}, \mathrm{P} 8 / 3 / 66 \\
207 / 63,220 / 68 \\
\text { B58,4607 }\end{array}$ \\
\hline B. canis & - & RM6-66 \\
\hline $\begin{array}{l}\text { B. neotomae } \\
\text { B. ovis } \\
\text { Yersinia enterocolitica }\end{array}$ & - & $\begin{array}{l}5 \mathrm{~K} 33 \\
\text { ST63/97 } \\
\text { Serotype IX, NCTCIO46I }\end{array}$ \\
\hline
\end{tabular}

$\mathrm{ND}=$ not done.

* Provided by Dr A. Philippon, Institut National de la Recherche Agronomique, Station de Pathologie de la Reproduction, Nouzilly, France.

recommended by the Subcommittee on Taxonomy of Brucella (Stableforth \& Jones, 1963; Jones, 1967) and included the type culture of each species examined. The strains were representatives of every biotype of Brucella maintained at this laboratory. Bacteria were cultured on serum dextrose agar or trypticase soya agar.

Protein extraction. Cells were harvested from two or more slopes using cold phosphatebuffered saline ( $100 \mathrm{mM}, \mathrm{pH} 7^{\circ}$ ) and washed once in the same diluent. Protein was extracted by emulsifying $100 \mathrm{mg}$ of bacteria in $100 \mu \mathrm{l}$ of phenol +acetic acid + water $(4: 2: \mathrm{I}$ parts by weight). The digest was centrifuged at $40000 \mathrm{~g}$ for $30 \mathrm{~min}$ and the supernatant fluid'retained. The extracts, which contained the acid + phenol soluble (APS) proteins, were stored at $-20^{\circ} \mathrm{C}$ unless they were required immediately.

Electrophoresis. Protein samples were separated in columns containing $7 \cdot 5 \%(\mathrm{w} / \mathrm{v})$ acrylamide, $5 \mathrm{M}$-urea and $35 \%(\mathrm{v} / \mathrm{v})$ aqueous acetic acid. These were prepared by adding $\mathrm{I} 2 \mathrm{ml}$ of stock solution A (acrylamide, $7.5 \mathrm{~g}$; urea, $30 \mathrm{~g} ; N, N^{\prime}$-methylenebisacrylamide, $0.2 \mathrm{~g}$; aqueous acetic acid $(35 \%, \mathrm{v} / \mathrm{v}$, to $100 \mathrm{ml})$ to $10 \mathrm{mg}$ of ammonium persulphate. The solution was degassed at 160 Torr for $5 \mathrm{~min}$, the vacuum released and $0.06 \mathrm{ml}$ of $N, N, N^{\prime}, N^{\prime}$-tetramethylethylenediamine added. This working solution was dispensed into glass running tubes ( $5 \mathrm{~mm}$ internal diam. $\times 75 \mathrm{~mm}$ length) to a height of $62 \mathrm{~mm}$, overlayed with a few drops of water and allowed to polymerize at $37^{\circ} \mathrm{C}$ for $90 \mathrm{~min}$. The gels were positioned vertically in the tank of an Analytical Polyacrylamide Electrophoresis Apparatus (Shandon Scientific Co. Ltd, London N.W. Io) with $10 \%(\mathrm{v} / \mathrm{v})$ aqueous acetic acid as the reservoir fluid. Between $50 \mu \mathrm{l}$ and $75 \mu \mathrm{l}$ of the APS protein sample were layered directly on to the gel through the surface of the acetic acid. (Previous experiments had shown that when APS protein fractions were prepared under standard conditions this volume contained 250 to $300 \mu \mathrm{g}$ of protein). The upper electrode served as the anode and a constant 


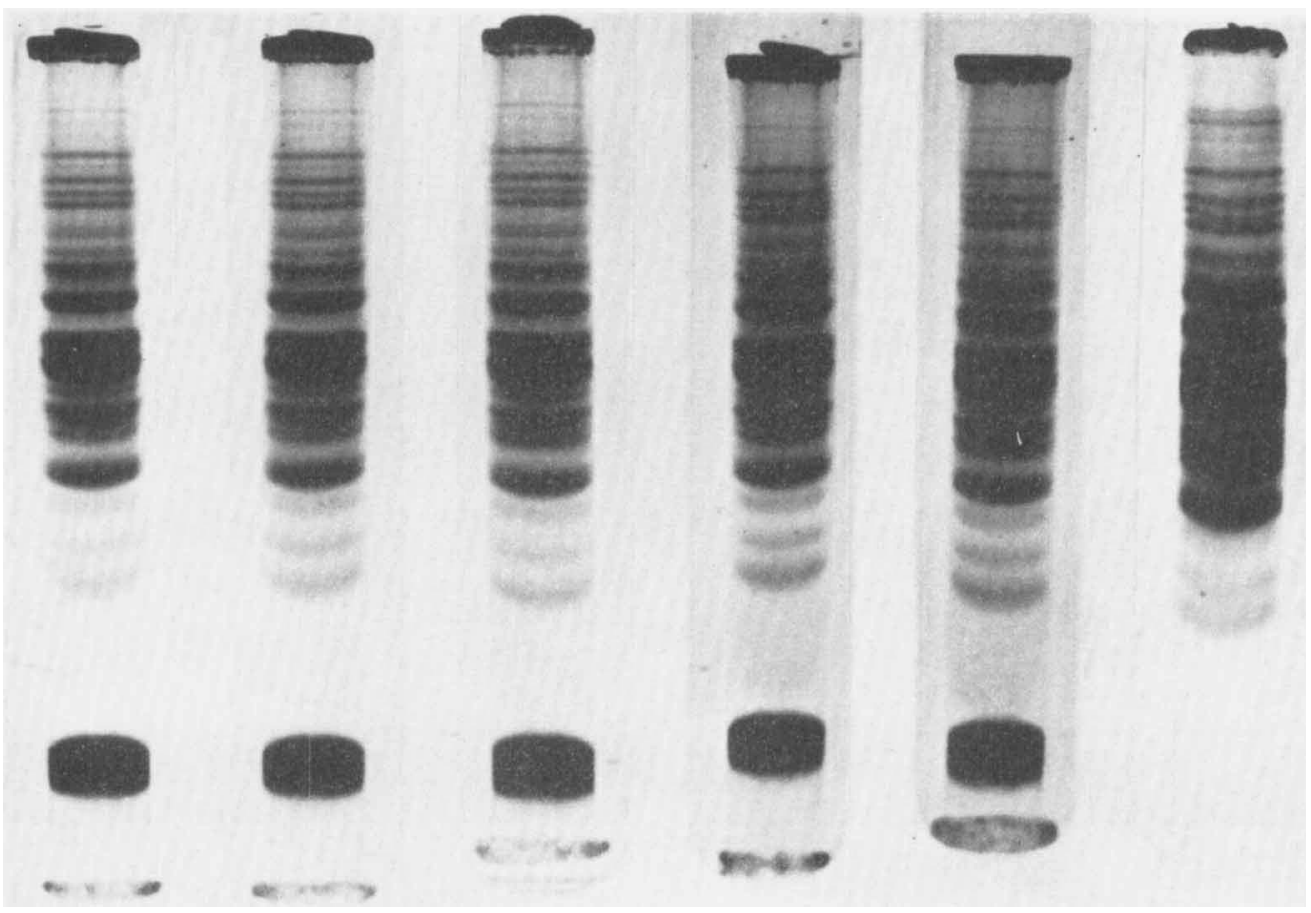

Fig. 1. Electrophoretic patterns of cell proteins from the type cultures of (a) Brucella abortus (544); (b) B. melitensis (I6M), (c) B. suis biotype I (I330), (d) B. neotomae (5K33), (e) B. ovis (sr63/97), (f) B. canis (RM6-66).

current equivalent to $3 \mathrm{~mA} / \mathrm{gel}$ was delivered from a Vokam Type $254 \mathrm{I}$ Power Pack (Shandon). After $15 \mathrm{~min}$ the current was increased to $5 \mathrm{~mA} / \mathrm{gel}$ for a further $60 \mathrm{~min}$. A reference gel, reserved for the APS protein sample from Brucella abortus s99, was included in every separation. The separated proteins were visualized by immersing the gels in $1.0 \%$ Amido Black (prepared in $7 \%(\mathrm{v} / \mathrm{v})$ aqueous acetic acid) for $30 \mathrm{~min}$ and removing unbound stain by washing in $30 \%(\mathrm{v} / \mathrm{v})$ aqueous acetic acid. In every experiment the protein patterns were compared with the pattern of the reference gel included in that experiment and not with gels from different experiments.

\section{RESULTS}

When separating APS proteins it was found to be extremely important to employ standard conditions at all times and only to compare protein patterns separated during the same experiment. When these points were observed the protein pattern of a strain was a constant feature which was usually reproducible. Even so, slight variation in the number of the minor bands was occasionally observed, but whenever this occurred repeat experiments using fresh extracts always produced the expected patterns. A large, heavily staining area was often observed near the bottom of the gels but this was not a true protein band as the strain was only present at the gel surface. (The artefact is seen in Fig. I $a$, for example, but is absent in Fig. I f.) Different growth media did not affect the protein patterns and there was no 


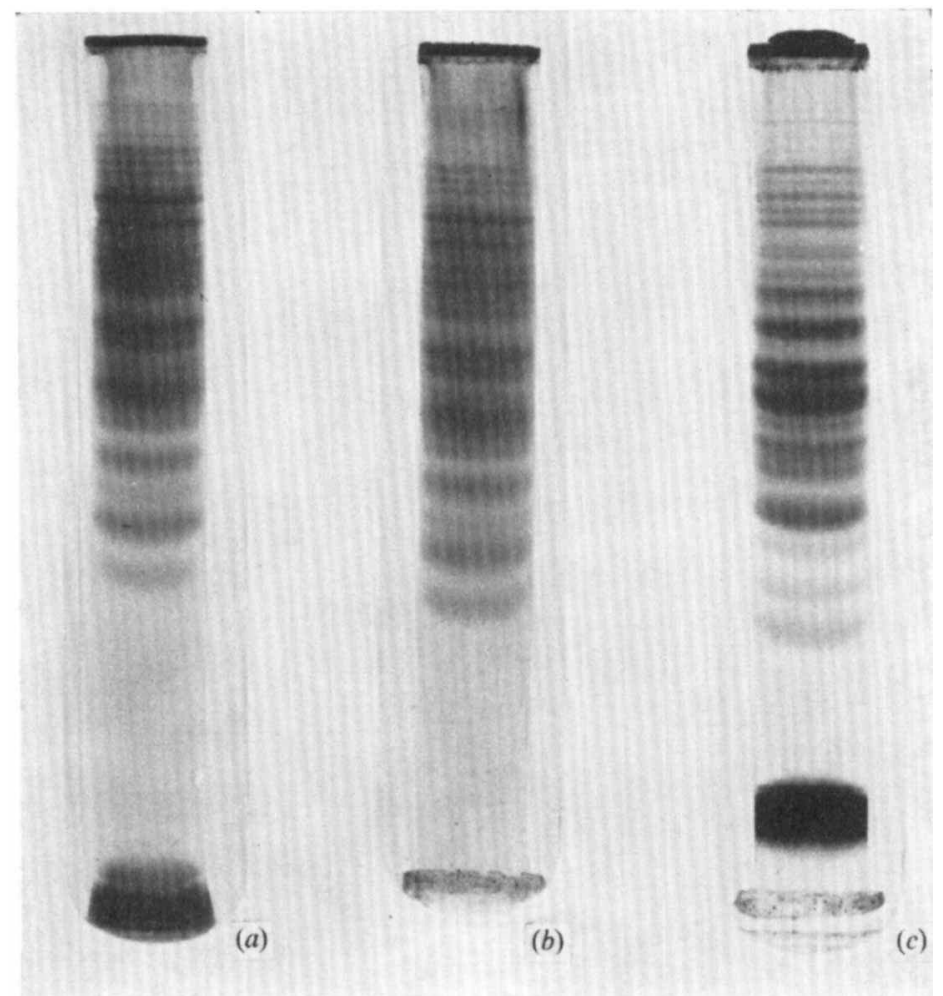

Fig. 2. Electrophoretic patterns of cell proteins of (a) Brucella suis biotype 5 (B58), (b) B. suis biotype 5 (4607), (c) B. suis biotype I (I330).

difference between the electrophoretograms of proteins from rough and smooth organisms. Similarly, the age of the culture did not affect the protein patterns.

The electrophoretic patterns of proteins from all the biotypes of Brucella abortus examined (biotype 8 was not available), all the biotypes of $B$. melitensis, $B$. suis biotypes I, 2, 3 and $4, B$. neotomae, $B$. ovis and $B$. canis were identical to each other. The patterns obtained from the type culture of each of the six species of Brucella are shown in Fig. I. The protein patterns of strain B 58 and strain 4607 , the two representatives of $B$. suis biotype 5 , were indistinguishable and, although they showed some similarity to those of the other brucellas, these two strains could easily be distinguished from the established members of the genus (Fig. 2). Yersinia enterocolitica $I X$ and $Y$. enterocolitica NCTCI046I gave identical protein patterns which were distinct from those of the established Brucella species (Fig. 3) and of the two representatives of $B$. suis biotype 5 .

\section{DISCUSSION}

From the similarity in the protein patterns of all the Brucella species (with the exception of Brucella suis biotype 5) it is apparent that the patterns obtained from polyacrylamide gel electrophoresis of the proteins reflect the overall relationship between the organisms classified as Brucella. Yersinia enterocolitica IX shows complete cross-agglutination with Brucella and tests with monospecific antiserum have shown that the cross-reacting antigen of $Y$. enterocolitica IX contains determinants of similar specificity to the A determinants of B. abortus 


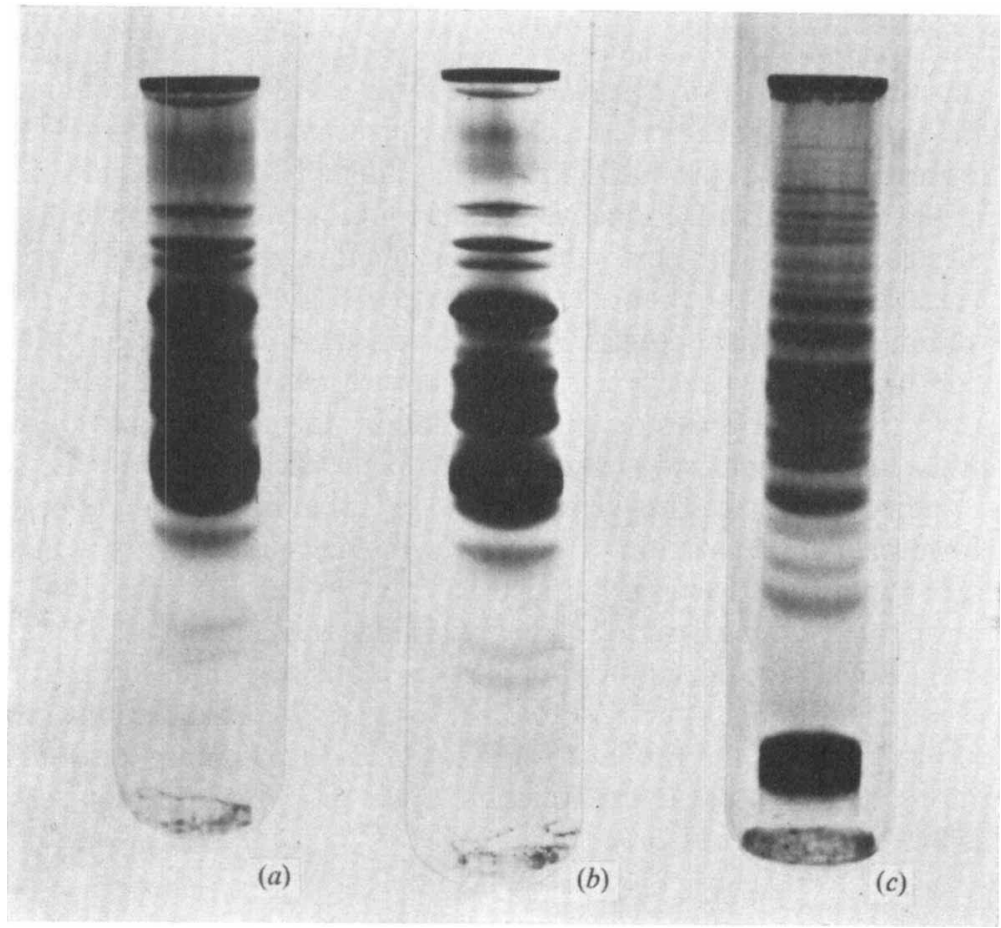

Fig. 3. Electrophoretic patterns of cell proteins of (a) Yersinia enterocolitica IX, (b) Y. enterocolitica NCTC 10461, (c) Brucella sp. (st63/97).

(Corbel \& Cullen, 1970). Yersinia enterocolitica NCTC 1046r does not cross-react serologically with Brucella. The protein electrophoretograms of the two Yersinia strains were identical but distinct from those produced from the Brucella cultures. Thus, the technique appears to differentiate at the generic level despite intergeneric serological cross-reaction.

The results indicate that Brucella neotomae (Stoenner \& Lackman, I957) is closely related to the three classical species and therefore that the organism has been assigned to the correct genus. Similarly, although the generic rank of $B$. ovis has been questioned in the past (e.g. Meyer \& Cameron, I956; Jones, I967) the results presented here suggest that the organism is a member of the genus Brucella. Diaz, Jones \& Wilson (1967) using serological techniques and Hoyer \& McCullough (1968a) using DNA homology techniques both reached similar conclusions. Recently a new member of the genus, $B$. canis, was described by Carmichael \& Bruner (I968). The DNA homology studies of Hoyer \& McCullough (I968 b) and the more conventional studies of Jones, Zanardi, Leong \& Wilson (I968) showed that the inclusion of this organism in the genus Brucella was justified. Again, bacterial protein electrophoretograms afford independent confirmation that the isolates of Carmichael \& Bruner (I968) are Brucella.

Strains B58 and 4607, isolated from cattle and sheep respectively, were two representatives of isolates claimed by Renoux \& Philippon (I969) to differ from the other biotypes of Brucella suis in their resistance to Safranin $O$ and in their oxidative metabolic patterns. These workers therefore proposed that their isolates be accepted as representatives of a new fifth biotype of $B$. suis (Renoux \& Philippon, 1969). Having demonstrated that the 36 Brucella cultures from the culture collection at this laboratory produced identical protein electro- 
phoretograms, it was immediately evident from the protein patterns of B58 and 4607 that these two organisms were not Brucella.

Clearly the taxonomic status of Brucella suis biotype 5 should be re-examined.

Polyacrylamide gel electrophoresis is a technique which should only be used for taxonomic purposes with great care as reproducibility can be difficult to attain and difficulties may arise in making objective comparisons between different gel patterns. Despite these problems, well-marked electrophoretic differences have been demonstrated both at the intergeneric level (Sacks, Haas \& Razin, I969) and at the interspecies level (Lund, I965; Razin, I968) using polyacrylamide gel electrophoresis. A degree of selectivity can be introduced into the technique by considering specific enzymes rather than a total protein mixture (e.g. Norris \& Burges, 1963; Norris, 1964). This not only eases the problem of comparison between gels but often has the effect of increasing the sensitivity of the technique (Morris, I97I). In the present work, studies on enzymes may have proved useful in distinguishing between species of Brucella. However, the preparation of extracts with enzymatic activity would necessitate not only a larger quantity of bacteria but also an extra step in the procedure to break the cells. These are important considerations when working with pathogens. The use of wholecell digests has the advantage of requiring only a small quantity of bacteria from which the protein can be extracted in one simple step. This, together with the demonstration that the electrophoretic properties of the proteins were not affected by colony dissociation, age or cultural conditions, suggests that the technique may be particularly useful in assigning new and unusual isolates to the genus Brucella.

\section{REFERENCES}

Carmichael, L. E. \& Bruner, D. W. (I968). Characteristics of a newly recognized species of Brucella responsible for infectious canine abortions. Cornell Veterinarian 58, 579-592.

CORBel, M. J. \& CULlen, G. A. (1970). Differentiation of the serological response to Yersinia enterocolitica and Brucella abortus in cattle. Journal of Hygiene 68, 519-530.

DiAz, R., Jones, L. M. \& WiLson, J. B. (1967). Antigenic relationship of Brucella ovis and Brucella melitensis. Journal of Bacteriology 93, I262-1 268.

GotTlieb, D. \& Hepden, P. M. (I966). The electrophoretic movement of proteins from various streptomyces species as a taxonomic criterion. Journal of General Microbiology 44, 95-IO4.

HaAs, H., Davidson, Y. \& SAcks, T. (1972). Taxonomy of mycobacteria studied by polyacrylamide gel electrophoresis of cell proteins. Journal of Medical Microbiology 5, 3I-37.

Heberlein, G. T., Deley, J. \& Tijtgat, R. (1967). Deoxyribonucleic acid homology and taxonomy of Agrobacterium, Rhizobium and Chromobacterium. Journal of Bacteriology 94, 116-124.

HiLL, L. R. (1966). An index of deoxyribonucleic acid base composition of bacterial species. Journal of General Microbiology 44, 419-436.

Hoyer, B. H. \& McCullough, N. B. (1968a). Polynucleotide homologies of Brucella deoxyribonucleic acids. Journal of Bacteriology 95, 444-448.

Hoyer, B. H. \& MCCullough, N. B. (1968b). Homologies of deoxyribonucleic acids from Brucella ovis, canine abortion organisms, and Brucella species. Journal of Bacteriology 96, 1783-1790.

JoNes, L. M. (1967). Report to the International Committee on Nomenclature of Bacteria by the Subcommittee on Taxonomy of Brucellae - minutes of meeting, July 1966. International Journal of Systematic Bacteriology I7, 37I-375.

Jones, L. M., Zanardi, M., Leong, D. \& Wilson, J. B. (I968). Taxonomic position in the genus Brucella of the causative agent of canine abortion. Journal of Bacteriology 95, 625-630.

Lund, B. M. (1965). A comparison by the use of gel electrophoresis of soluble protein components and esterase enzymes of some group D streptococci. Journal of General Microbiology 40, 413-419.

MeYer, M. E. \& CAMERon, H. S. (1956). Studies on the aetiological agent of epididymitis in rams. American Journal of Veterinary Research 17, 495-497.

Morris, J. A. (1971). Studies on Campylobacter spp. (microaerophilic vibrios). Ph.D. Thesis, University of Reading. 
MorRIS, J. A. \& PARK, R. W. A. (1970). The use of polyacrylamide gel electrophoresis of cell proteins to differentiate between microaerophilic vibrios. Journal of Applied Bacteriology 33, iv.

Norris, J. R. (1964). The classification of Bacillus thuringiensis. Journal of Applied Bacteriology 27, 439-447.

NorRIS, J. R. \& BuRGES, H. D. (1963). Esterases of crystalliferous bacteria pathogenic for insects: epizootiological applications. Journal of Insect Pathology 5, 460-472.

Razin, S. (1968). Mycoplasma taxonomy studied by electrophoresis of cell proteins. Journal of Bacteriology 96, 687-694.

RAzIN, S. \& RotTeM, S. (I967). Identification of Mycoplasma and other microorganisms by polyacrylamide gel electrophoresis of cell proteins. Journal of Bacteriology 94, I807-1810.

Renoux, G. \& Philippon, A. (1969). Position taxonomique dans le genre Brucella de bactéries isolées de brebis et de vaches. Annales de l'Institut Pasteur II7, 524-528.

SaCKS, T. G., HaAS, H. \& Razin, S. (1969). Polyacrylamide gel electrophoresis of cell proteins of Enterobacteriaceae. Israel Journal of Medical Science 5 (I), 49-55.

Stableforth, A. W. \& Jones, L. M. (1963). Report of the Subcommittee on Taxonomy of the genus Brucella. Speciation of the genus Brucella. International Bulletin of Bacteriological Nomenclature and Taxonomy I3, I45-I 58.

StoenNeR, H. G. \& LACKMAN, D. B. (1957). A new species of Brucella isolated from the desert wood rat, Neotomae lepida, Thomas. American Journal of Veterinary Research r8, 947-95 I. 